\title{
Effects of Oil Price Shocks and Economic Fluctuations of Trading Partners on Iran's Ports Throughput
}

\author{
Mehdi Mirzaeia, Hojat Parsab
}

This study aims to estimate the effects of oil price shocks on seaborne trade in Iran; in particular, port throughput of three leading ports through economic fluctuations of three major trading partners of Iran, based on quarterly data for the period of 1999Q2 to 2018Q1. We apply a standard vector autoregressive (VAR) approach using Cholesky decomposition. The results indicate that with increasing oil revenues in short-run, seaborne trade be further directed towards Shahid Rajaei port while rising oil revenues changes the combination of goods handled in Emam Khomeini and Bushehr ports. In the long run, the share of oil price fluctuations in explaining the variations of Shahid Rajaei port throughput is higher than the other two. In fact, increases in oil revenues cause an increase in the volume of industrial and containerized seaborne cargo trade.

\section{KEY WORDS}

$\sim$ Oil price shocks

$\sim$ Port throughput

$\sim$ VAR

$\sim$ Vector autoregressive

$\sim$ Iran's major ports

\section{INTRODUCTION}

With the increasing importance of globalization as well as the acceleration of economic integration among different countries, maritime transportation is playing an important role in facilitating global trade. Ports are the backbones of seaborne trade. According to UNCTAD reports, global trade in 2016 reached 10.3 billion tons after a steady increase during the last seven years. Since 2009, the goods' volume loaded and discharged in ports worldwide has grown by 2.4 billion tons. Mainly, the trade of dry cargo, petroleum products, and gas by sea has increased (UNCTAD, 2017). As stated by the Iran's Ports and Maritime Organization, between 2017Q2 and 2018Q1 over 156.8 million tons of cargo were loaded and discharged in the ports of Iran, which included 47.7 million tons of petroleum products, 4.4 million tons of liquid bulk, 51.2 million tons of dry bulk, 30.8 million tons of containerized cargo, and 4.22 million tons of general cargo. These demonstrate the vital importance of maritime transportation in the foreign trade of Iran (Iran's Port and Maritime Organization, 2018). Therefore, if port authorities wish to establish competitive strategies, and plan and manage logistics as well as transportation infrastructures, they should identify factors affecting port throughput (Kim, 2016).

Undoubtedly, oil price shocks are of the factors affecting the trade volume in different countries, particularly in oil-exporting countries. Economou and Agnolucci (2016) categorized oil price shocks in two major groups: oil supply shocks and oil demand shocks. From the supply perspective, positive and negative shocks of oil prices are caused either by events outside the oil market (exogenous) or as a result of the normal functioning of the oil market (endogenous). Taghizadeh Hesary et al. (2013) stated that when oil prices rise, it is expected to have a direct positive 
effect on oil exporting countries that are raising oil revenues. On the other hand, for oil-importing countries this price increase is considered as a negative supply shock. As a result, the energy importer's demand is reduced, and this indirect effect is expected to be negative for oil-exporting countries. This adverse effect will increase the energy-exporting country's revenue lower than expected. Also, increasing revenues of oil-exporting countries will enable oil-importing countries to export more goods to these countries, which has a direct positive effect on the foreign trade sector of oil-exporting countries' trading partners.

Furthermore, world seaborne trade continues to be largely determined by developments in the world economy and trade. Although the relationship between economic output and merchandise trade seems to be shifting, with an observed decline in the growth ratio of trade to the gross domestic product over the recent years, the demand for maritime transport services remains heavily dependent on the performance of the world economy. Thus, industrial activity, economic output, merchandise trade, and seaborne trade shipments are positively correlated (UNCTAD, 2017).

Iran is the second largest oil producer in the Organization of the Petroleum Exporting Countries (OPEC, 2005). In such circumstances, any shock in oil markets could have a huge impact on Iran's economic structure. An examination of the structure of foreign trade in OPEC member countries shows that the major share of exports in these countries is dedicated to oil and petroleum products. On the other hand, import in these countries depends heavily on foreign exchange earnings from oil exports. As a result, any change in oil prices will affect imports, production, and economic growth in these countries. Therefore, the analysis of various perspectives of foreign trade in OPEC member countries is important. These countries have similar trading partners. The majority of exports in these countries are to countries such as the United States, Germany, England, France, Italy, China, Japan, Spain, India, South Korea, and the Netherlands. Thus, analyzing the effects of economic fluctuations of OPEC member trading partners is a central issue in the development of foreign trade in these countries.

As stated above, seaborne trade and especially ports are the leading actors in the foreign trade sector in every country. This study aims to investigate the effects of oil price shocks on port throughput in three major ports in Iran through economic fluctuations of its three major trading partners. Some research works have studied the effects of shocks to oil prices on macroeconomic variables in oil-exporting countries (Korhonen and Ledyaeva, 2010; Le and Chang, 2013; Raheem, 2017). Another group of studies estimated the effect of oil price volatilities on terms of trade and real effective exchange rate in oil exporting countries (Dauvin, 2014; Volkov and Yuhn, 2016; Basher et al., 2016; Chen et al., 2016). The results of all these studies indicate that oil price shocks affect the trade sector of oil-exporting countries in the long run and short run, and this impact varies depending on the economic development and dependence of these countries on oil export. Farzanegan and Markwardt (2007) studied the dynamic relationship between oil price shocks and macroeconomic variables in Iran using a VAR approach. The results showed that on the supply side of the economy, rising oil prices would increase terms of trade and the real exchange rate. Furthermore, Hesary et al. (2013) evaluated the impacts of oil price shocks on oil-producing and consuming economies. The results indicated that oil producers (Iran and Russia) benefit from indirect effects through their trading partners. What distinguishes this research from previous studies is that this research is the first attempt to study the impacts of oil price shocks on Iran's seaborne trade through trading partners.

This study uses quarterly data from 1999 Q2 to 2018 Q1, i.e. a period that covers US military strike on Iraq in 2003 and U.S economic sanction against Iran. It analyses the impacts of oil price shocks on the port throughput of three major ports in Iran, i.e. Shahid Rajaei, Emam Khomeini, and Bushehr, through economic fluctuations of Iran's major trading partners. The sample of trading partners consists of three countries: China, South Korea, and Germany. Since the volatility of each port throughput directly and indirectly affects the port's income, the volume of investment in the port, the level of employment, the results of this study can provide policy insights to help port authorities' policymakers to develop seaborne trade policies.

The following sections of the paper are structured as follows: data used in the study is described in Section 2; Section 3 discusses the VAR methodology applied; Section 4 presents the empirical results, and Section 5 summarizes the main results.

\section{DATA}

In this paper, we use ten variables: seasonal average of Iran's heavy crude oil spot price (LIROP), Gross Domestic Product (GDP) in constant market prices of 2010 for China, Germany, and South Korea (LGDPCH, LGDPGE, LGDPKO) as representative of economic fluctuations of the major trading partners, tonnage of goods loaded and discharged in Shahid Rajaei, Emam Khomeini as well as Bushehr ports (LRALOUN, LEMLOUN, LBULOUN), and the number of vessels handled by sample ports (LRAVH, LEMVH, LBUVH). The tonnage of goods loaded and discharged, and the numbers of vessels handled by ports are used as indicators of port throughput. 
The oil price refers to the spot price of the benchmark barrel of different crude oils. The seasonal average of Iran's heavy crude oil price is derived from Iran's heavy oil spot prices (\$/B), monthly data of OPEC Reference Basket (ORB), and corresponding components' spot prices (Figure 1). As shown in Figure 1, oil price trend is unpredictable and high volatility is a key characteristic in this market.

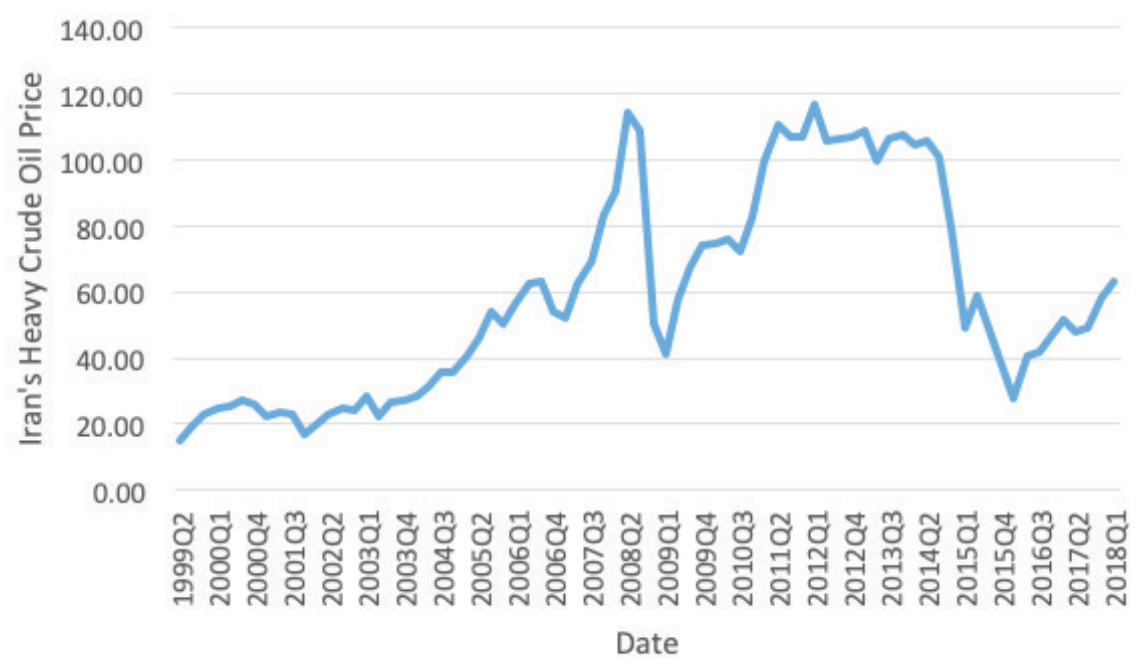

Figure 1.

The Seasonal average of Iran's heavy crude oil price (\$/B) (Source: OPEC 2018).

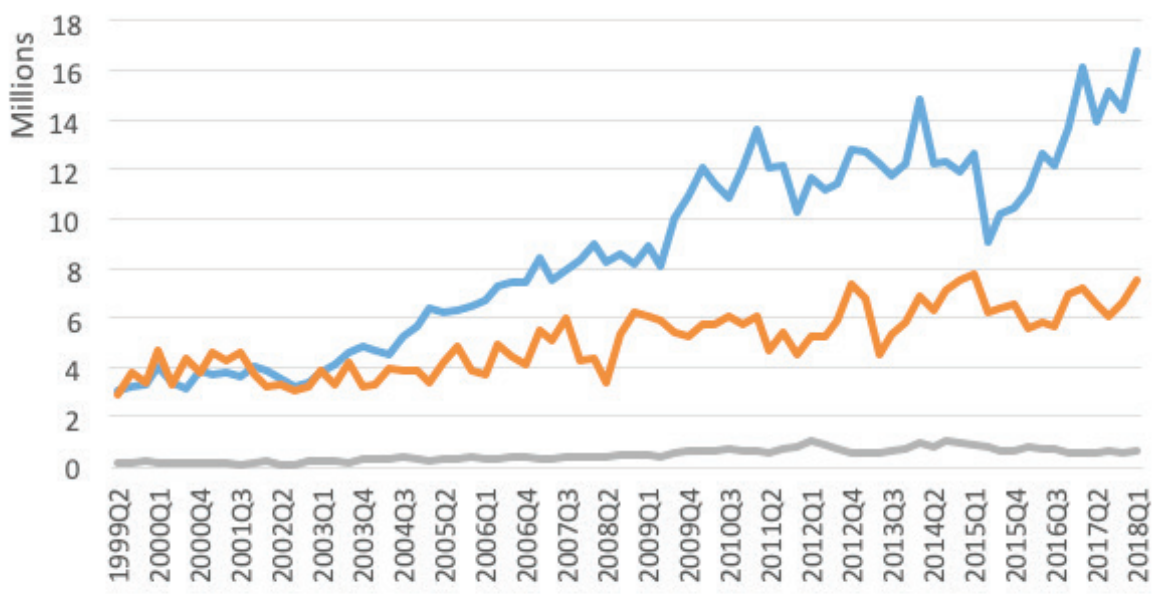

Shahid Rajaei —Emam Khomeyni $\longrightarrow$ Bushehr

Figure 2.

Tonnage of goods loaded and discharged in Iran's major ports (tons) (Source: Iran's Port and Maritime Organization 2018). 


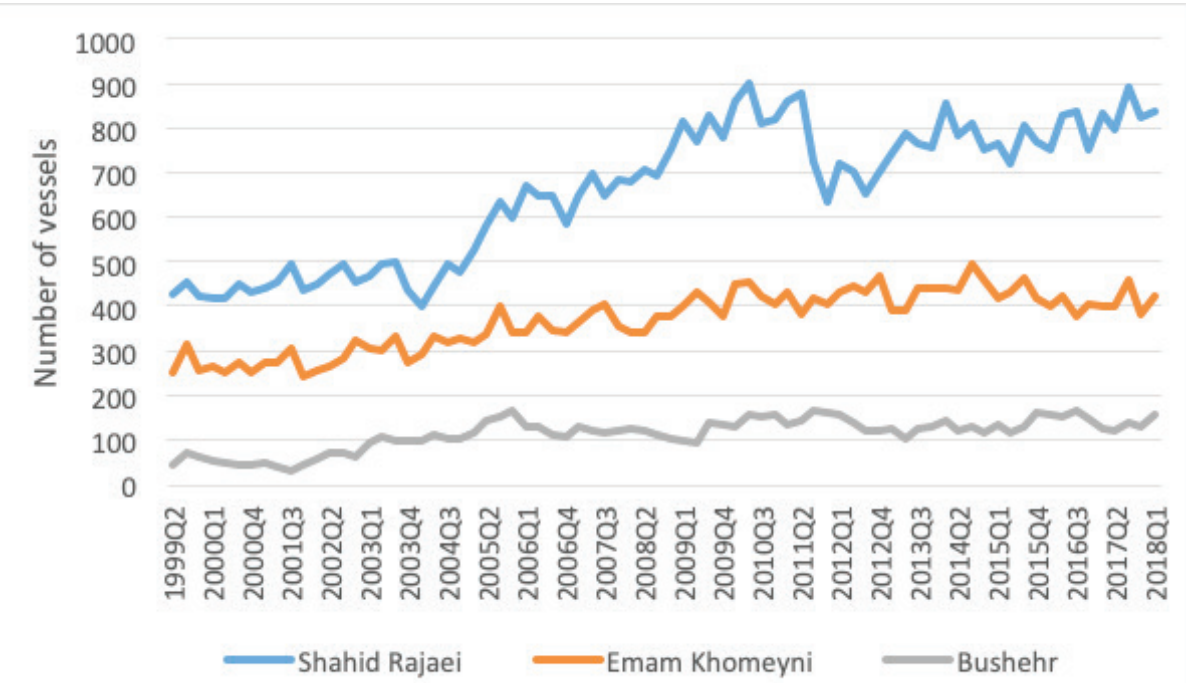

Figure 3.

Number of vessels handled by Iran's major ports (Source: Iran's Port and Maritime Organization 2018).

GDP in constant prices of 2010 is the sum of gross value added by all the resident producers in the economy, plus any product taxes, and minus any subsidies not included in the value of the products. It is calculated without making deductions for depreciation of fabricated assets or depletion and degradation of natural resources. Data are in constant 2010 U.S. dollars. Dollar figures for GDP are converted from domestic currencies using 2010 official exchange rates.

The United States Bureau of Transportation (2017) defines port throughput as the amount of cargo or number of vessels a port handles over time. The tonnage of goods loaded and discharged for each port is the loading and unloading tonnage of non-oil cargoes including dry bulk, liquid bulk, containerized, and general cargoes. In addition, the number of vessels handled by each port includes vessels whose deadweight tonnage ${ }^{1}$ is greater than or equal to 1,000 tons. For this research, data for the throughput of each port were obtained from Iran's Port and Maritime Organization data portal (Figures 3 and 4).

In order to take into account the effects of the Joint Comprehensive Plan of Action (JCPOA), we have employed a dummy variable (D1) ${ }^{2}$. After 2010, when sanctions became more comprehensive, and oil price decreased to 60 dollars per barrel in 2009 , the exports reduced dramatically to about 20 billion dollars

1. It is a measure of how much a vessel can carry.

2. The JCPOA or the Iran Nuclear deal was signed on July 14, 2015 by Iran and five permanent members of the UN Security Council plus Germany. It officially went into effect in January 2016. in 2010. Besides, oil export was reduced to 1 million barrels per day. After the removal of sanctions in the first half of 2017, the exports were increased to an average of 50 billion dollars, and the imports reached 40 billion dollars. Also, during the same period oil exports rose from 1 million barrels per day to nearly 2.5 million barrels per day (Mehdi-Zadeh, 2018).

\section{METHODOLOGY}

In order to investigate the response of Iran's major ports throughput to changes in Iran's crude oil prices and economic fluctuations of Iran's three major trading partners, we apply a standard vector autoregressive approach. The VAR approach provides us with a framework in which changes in a variable are related to changes in its own lags and changes in other variables plus the lags of those variables (Farzanegan and Markwardt, 2017). This approach emphasizes that in modelling, and especially in determining the endogenous and exogenous variables, all variables should be considered as endogenous. In the analysis of VAR models and the use of their results, Forecast Error Variance Decomposition and Impulse Response Functions (IRF) are usually used. Less attention is paid to criteria such as the significance of the coefficients using t statistic; since in VAR models the explanatory variables usually have strong multicollinearity, $t$ statistics cannot be a reliable criterion for the suitability of variables. Our standard VAR model of order $p$ is presented in Equation 1: 
in which $z_{t}$ is the vector of exogenous variables, $y_{t}$ is the vector of endogenous variables, $\varepsilon_{t}$ is the innovation process, $A_{i}$ and $B$ are coefficient matrices, and $p$ is the lag length. In the present study, the vector of endogenous variables for each

$y_{t}=A_{1} y_{t}+\ldots+A_{p} y_{t-p}+B z_{t}+\varepsilon_{t}$
VAR model, according to Cholesky decomposition, includes the seasonal average of Iran's heavy crude oil price (LIROP), GDP in the constant market prices of 2010 for China, Germany, and South Korea (LGDPCH, LGDPGE, LGDPKO), number of vessels handled by each port (LRAVH, LEMVH, LBUVH), and tonnage of goods loaded and discharged in each port (LRALOUN, LEMLOUN, LBULOUN). Given the optimal lag length of one, VAR models can be presented as the matrix forms below:

\begin{tabular}{|c|c|c|c|c|c|c|c|c|c|c|c|c|}
\hline $\left.\begin{array}{c}\operatorname{LRAVH}_{t} \\
\operatorname{LRALOUN}_{t} \\
\operatorname{LIROP}_{t} \\
\operatorname{LGDPCH}_{t} \\
\operatorname{LGDPGE}_{t} \\
\text { LGDPKO }_{t}\end{array}\right]$ & $=$ & $\left.\begin{array}{l}V_{1} \\
V_{2} \\
V_{3} \\
V_{4} \\
V_{5} \\
V_{6}\end{array}\right]$ & + & $\begin{array}{l}A_{11} \\
A_{21} \\
A_{31} \\
A_{41} \\
A_{51} \\
A_{61}\end{array}$ & $\begin{array}{l}A_{12} \\
A_{22} \\
A_{32} \\
A_{42} \\
A_{52} \\
A_{62}\end{array}$ & $\begin{array}{l}A_{13} \\
A_{23} \\
A_{33} \\
A_{43} \\
A_{53} \\
A_{63}\end{array}$ & $\begin{array}{l}A_{14} \\
A_{24} \\
A_{34} \\
A_{44} \\
A_{54} \\
A_{64}\end{array}$ & $\begin{array}{l}A_{15} \\
A_{25} \\
A_{35} \\
A_{45} \\
A_{55} \\
A_{65}\end{array}$ & $\begin{array}{l}A_{16} \\
A_{26} \\
A_{36} \\
A_{46} \\
A_{56} \\
A_{66}\end{array}$ & $\left.\begin{array}{c}L^{L R A V H} H_{t-1} \\
\operatorname{LRALOUN}_{t-1} \\
\operatorname{LIROP}_{t-1} \\
\operatorname{LGDPCH}_{t-1} \\
\operatorname{LGDPGE}_{t-1} \\
\text { LGDPKO }_{t-1}\end{array}\right]$ & + & $\begin{array}{l}u_{1 t} \\
u_{2 t} \\
u_{3 t} \\
u_{4 t} \\
u_{5 t} \\
u_{6 t}\end{array}$ \\
\hline $\left.\begin{array}{c}\text { LEMVH }_{t} \\
\text { LEMLOUN }_{t} \\
\text { LIROP }_{t} \\
\text { LGDPCH }_{t} \\
\text { LGDPGE }_{t} \\
\text { LGDPKO }_{t}\end{array}\right]$ & $=$ & $\begin{array}{l}V_{1} \\
V_{2} \\
V_{3} \\
V_{4} \\
V_{5} \\
V_{6}\end{array}$ & + & $\begin{array}{l}A_{11} \\
A_{21} \\
A_{31} \\
A_{41} \\
A_{51} \\
A_{61}\end{array}$ & $\begin{array}{l}A_{12} \\
A_{22} \\
A_{32} \\
A_{42} \\
A_{52} \\
A_{62}\end{array}$ & $\begin{array}{l}A_{13} \\
A_{23} \\
A_{33} \\
A_{43} \\
A_{53} \\
A_{63}\end{array}$ & $\begin{array}{l}A_{14} \\
A_{24} \\
A_{34} \\
A_{44} \\
A_{54} \\
A_{64}\end{array}$ & $\begin{array}{l}A_{15} \\
A_{25} \\
A_{35} \\
A_{45} \\
A_{55} \\
A_{65}\end{array}$ & $\begin{array}{l}A_{16} \\
A_{26} \\
A_{36} \\
A_{46} \\
A_{56} \\
A_{66}\end{array}$ & $\left.\begin{array}{c}L^{L R A V H} H_{t-1} \\
\operatorname{LRALOUN}_{t-1} \\
\operatorname{LIROP}_{t-1} \\
\operatorname{LGDPCH}_{t-1} \\
\operatorname{LGDPGE}_{t-1} \\
\text { LGDPKO }_{t-1}\end{array}\right]$ & + & $\begin{array}{l}u_{1 t} \\
u_{2 t} \\
u_{3 t} \\
u_{4 t} \\
u_{5 t} \\
u_{6 t}\end{array}$ \\
\hline $\left.\begin{array}{c}L^{L B U V H} H_{t} \\
\operatorname{LBULOUN}_{t} \\
\operatorname{LIROP}_{t} \\
\operatorname{LGDPCH}_{t} \\
\operatorname{LGDPGE}_{t} \\
\text { LGDPKO }_{t}\end{array}\right]$ & $=$ & $\begin{array}{l}V_{1} \\
V_{2} \\
V_{3} \\
V_{4} \\
V_{5} \\
V_{6}\end{array}$ & + & $\begin{array}{l}A_{11} \\
A_{21} \\
A_{31} \\
A_{41} \\
A_{51} \\
A_{61}\end{array}$ & $\begin{array}{l}A_{12} \\
A_{22} \\
A_{32} \\
A_{42} \\
A_{52} \\
A_{62}\end{array}$ & $\begin{array}{l}A_{13} \\
A_{23} \\
A_{33} \\
A_{43} \\
A_{53} \\
A_{63}\end{array}$ & $\begin{array}{l}A_{14} \\
A_{24} \\
A_{34} \\
A_{44} \\
A_{54} \\
A_{64}\end{array}$ & $\begin{array}{l}A_{15} \\
A_{25} \\
A_{35} \\
A_{45} \\
A_{55} \\
A_{65}\end{array}$ & $\begin{array}{l}A_{16} \\
A_{26} \\
A_{36} \\
A_{46} \\
A_{56} \\
A_{66}\end{array}$ & $\left.\begin{array}{c}\text { LRAVH }_{t-1} \\
\operatorname{LRALOUN}_{t-1} \\
\operatorname{LIROP}_{t-1} \\
\operatorname{LGDPCH}_{t-1} \\
\operatorname{LGDPGE}_{t-1} \\
\operatorname{LGDPKO}_{t-1}\end{array}\right]$ & + & {$\left[\begin{array}{l}u_{1 t} \\
u_{2 t} \\
u_{3 t} \\
u_{4 t} \\
u_{5 t} \\
u_{6 t}\end{array}\right]$} \\
\hline
\end{tabular}

We assume that the first variable in the pre-specified ordering of variables has a significant impact on the dynamics of VAR models. In the ordering of all three equations, oil price shocks are considered as the most important endogenous variables. Since Iran is one of the main suppliers of crude oil in the world, and crude oil is the main source of government revenues, many macroeconomic variables such as terms of trade and real exchange rates are affected by oil price fluctuations, which as a result affects the trade sector of the country and trade relationships with major trading partners.

It is argued that if variables follow a I(1) process, we should not use their first differences because in VAR models the aim is to determine the correlation between the variables, not the estimation of the parameters. Moreover, Sims (1980) stated that differencing might cause losing information when there are cointegration vectors in a model.

In the first step, we need to check the order of integration of our variables and the existence of cointegrating vectors. Augmented Dickey-Fuller (1979) and Philips-Perron (1983) tests have been applied to examine the order of integration. The results are shown in Table 1 . The results for both tests indicate that all the variables follow I (1) process. Considering that all the variables are stationary after first differencing, we analyze the existence of a relationship among the variables in the long run. Johansen cointegration tests (see Johansen, 1991, 1995) with considering all the five deterministic trend models are used. The number of cointegrating relations is shown in Tables 2 to 4. The results indicate the existence of a long-run relationship between variables. The optimal lag length is determined based on the Schwarz information criterion (SC), and Hannan-Quinn information criterion (HQ) for each VAR model is 1. The details of lag length selection are presented in Tables $A 1$ to $A 3$ in Appendix 
A. The results of Impulse-Response Functions and Forecast Error Variance Decomposition tables for each VAR model are presented in the next section.

\section{EMPIRICAL RESULTS}

\subsection{Unit Root Tests}

As stated by Granger and Newbold (1974), if all the variables in a model have a unit root, the model will encounter spurious regression. In this study, both Augmented Dickey-Fuller and Philips-Perron tests have been applied to specify the integration order for each variable. Table 1 presents the results. Each test has been applied with and without trend. At 5 per cent significant level, the null hypothesis of a unit root test has been rejected in both tests. Referring to the results, the variables are stationary after the first differencing. Since all the variables have unit root,
OLS 3 regressions cannot be used. If all variables are stationary after the first differencing, we can apply VAR econometric approach.

\subsection{Johansen Cointegration Test}

Considering that the variables of the models follow a I(1) process, in a second step we analyze the existence of long-run relationships among these variables. In the present article, Johansen cointegration test is accomplished in order to determine long-run relationships between the seasonal average of Iran's heavy crude oil price, Gross Domestic Product in the constant market prices of 2010 for three Iran's major trading partners, and Iran's major ports throughput. The number of cointegrating relations for each VAR model is shown in Tables 2 to 4 , at a 5 per cent significance level and using trace as well as maximal eigenvalue statistics. In order to specify the lag

Table 1.

Unit Root tests.

\begin{tabular}{|c|c|c|c|c|c|c|}
\hline & & \multirow{2}{*}{$\begin{array}{c}\text { ADF } \\
\text { Without trend }\end{array}$} & \multicolumn{3}{|c|}{ PP } & \multirow{2}{*}{$\begin{array}{l}\text { Integration } \\
\text { degree }\end{array}$} \\
\hline & & & With trend & Without trend & With trend & \\
\hline \multirow[t]{2}{*}{ LIROP } & Level & -2.18 & -1.77 & -2.20 & $-1.86-7.43^{*}$ & $\mathrm{I}(1)$ \\
\hline & 1st diff. & $-7.45^{*}$ & $-7.46^{*}$ & $-7.40^{*}$ & & \\
\hline \multirow[t]{2}{*}{ LGDPCH } & Level & $-3.19 *$ & 1.37 & -2.28 & 0.61 & $\mathrm{I}(1)$ \\
\hline & 1st diff. & $-5.55^{*}$ & $-6.17^{*}$ & $-5.44^{*}$ & $-6.17^{*}$ & \\
\hline \multirow[t]{2}{*}{ LGDPGE } & Level & -0.35 & -2.95 & -0.41 & -2.53 & $\mathrm{I}(1)$ \\
\hline & 1st diff. & $-5.50^{*}$ & $-5.48^{*}$ & $-5.46^{*}$ & $-5.44^{*}$ & \\
\hline \multirow[t]{2}{*}{ LGDPKO } & Level & $-3.23^{*}$ & -2.97 & $-3.08^{*}$ & -2.96 & $\mathrm{I}(1)$ \\
\hline & 1st diff. & $-6.89 *$ & $-7.31^{*}$ & $-6.84^{*}$ & $-7.25^{*}$ & \\
\hline \multirow[t]{2}{*}{ LRAVH } & Level & -1.58 & -2.81 & -1.33 & -2.66 & $\mathrm{I}(1)$ \\
\hline & 1st diff. & $-10.91^{*}$ & $-10.84^{*}$ & $-11.81^{*}$ & $-11.79 *$ & \\
\hline \multirow[t]{2}{*}{ LRALOUN } & Level & -1.01 & -2.71 & -0.98 & -2.51 & $\mathrm{I}(1)$ \\
\hline & 1st diff. & -11.35 & -11.29 & -12.06 & -12.01 & \\
\hline \multirow[t]{2}{*}{ LEMVH } & Level & -1.55 & $-4.80^{*}$ & -2.24 & $-4.95^{*}$ & $\mathrm{I}(1)$ \\
\hline & 1st diff. & $-9.68^{*}$ & $-9.67^{*}$ & $-19.64^{*}$ & $-20.97^{*}$ & \\
\hline \multirow[t]{2}{*}{ LEMLOUN } & Level & $-3.10^{*}$ & $-6.12^{*}$ & -2.91 & $-6.20^{*}$ & $\mathrm{I}(1)$ \\
\hline & 1st diff. & $-13.09^{*}$ & $-12.98^{*}$ & $-48.83^{*}$ & $-49.44^{*}$ & \\
\hline \multirow[t]{2}{*}{ LBUVH } & Level & -2.19 & -2.62 & -2.11 & -2.61 & $\mathrm{I}(1)$ \\
\hline & 1st diff. & $-9.24^{*}$ & $-9.14^{*}$ & $-9.34^{*}$ & $-9.22^{*}$ & \\
\hline \multirow[t]{2}{*}{ LBULOUN } & Level & -2.19 & $-3.48^{*}$ & -2.03 & $-3.51^{*}$ & $\mathrm{I}(1)$ \\
\hline & 1st diff. & $-9.98^{*}$ & $-7.27^{*}$ & $-14.21^{*}$ & $-16.71^{*}$ & \\
\hline
\end{tabular}

3. Ordinary Least Squares. 
length needed for Johansen cointegration test, variables are entered into a VAR model. The lag length is determined based on the Schwarz information criterion (SC) and Hannan-Quinn information criterion (HQ). According to the results, there are strong long-run relationships among the variables. Therefore, we can evaluate the dynamics of the models over the long run using Forecast Error Variance Decomposition.

Table 2 .

Johansen cointegration test for VAR model of Shahid Rajaei Port.

\begin{tabular}{llllll} 
Data Trend: & None & None & Linear & Linear & Quadratic \\
\hline Test Type & No Intercept & Intercept & Intercept & Intercept & Intercept \\
\hline & No Trend & No Trend & No Trend & Trend & Trend \\
\hline Trace & 3 & 3 & 2 & 2 & 1 \\
Max-Eig & 3 & 3 & 1 & & 1
\end{tabular}

Table 3.

Johansen cointegration test for VAR model of Emam Khomeyni Port

\begin{tabular}{llllll} 
Data Trend: & None & None & Linear & Linear & Quadratic \\
\hline Test Type & No Intercept & Intercept & Intercept & Intercept & Intercept \\
\hline & No Trend & No Trend & No Trend & Trend & Trend \\
\hline Trace & 4 & 4 & 4 & 3 & 3 \\
\hline Max-Eig & 4 & 4 & 3 & & 3
\end{tabular}

Table 4.

Johansen cointegration test for VAR model of Bushehr Port.

\begin{tabular}{|c|c|c|c|c|c|}
\hline Data Trend: & None & None & Linear & Linear & Quadratic \\
\hline Test Type & No Intercept & Intercept & Intercept & Intercept & Intercept \\
\hline & No Trend & No Trend & No Trend & Trend & Trend \\
\hline Trace & 5 & 5 & 6 & 3 & 3 \\
\hline Max-Eig & 5 & 4 & 3 & 1 & 1 \\
\hline
\end{tabular}

\subsection{Impulse Response Functions}

Impulse response functions indicate how each variable in a VAR model responds to the shocks. We trace the effects of a one-time shock to the seasonal average of Iran's heavy crude oil price as well as the real GDP of China, Germany, and South Korea on short-run values of the number of vessels handled by ports and the tonnage of goods loaded and discharged in Iran's major ports. The following subsections illustrate and explain IRFs for the VAR model of each port.

\section{Shahid Rajaei Port}

As shown in Figure 4, the IRFs for Shahid Rajaei Port's throughput VAR model indicate that the initial shock in oil prices significantly increases both the number of vessels handled plus the tonnage of goods loaded and discharged in this port, which hits a peak after the third period. This implies increasing the seaborne trade of this port both regionally and internationally. Since this port is Iran's largest commercial port, such an impact is expected. Shocks to GDPs of China and South Korea increase Shahid Rajaei's port throughput marginally, while a shock to Germany's GDP decreases it in the short-run. 


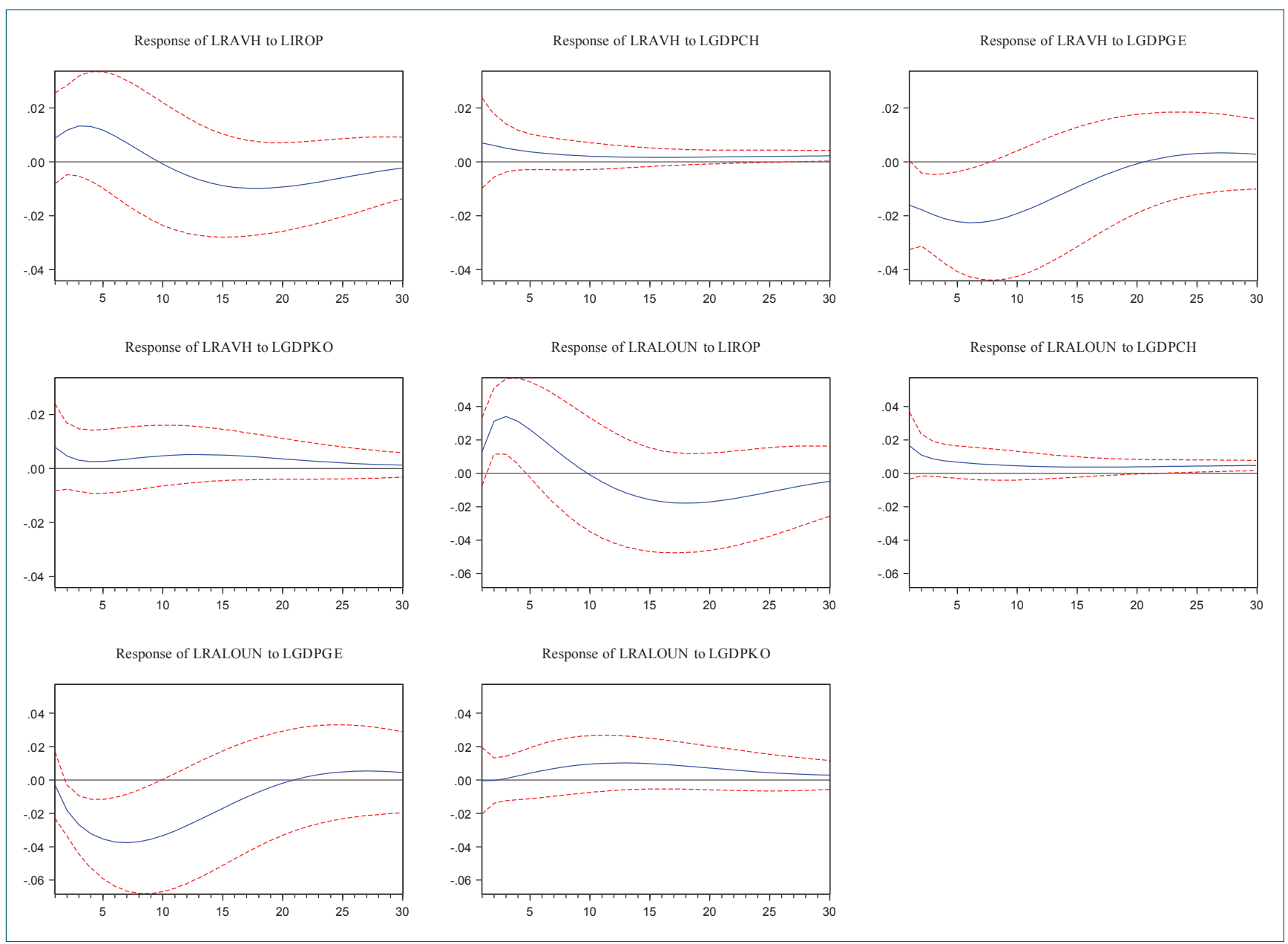

Figure 4.

IRFs for Shahid Rajaei port VAR model.

\section{Emam Khomeini Port}

Based on IRFs for Emam Khomeini port throughput shown in Figure 5, it can be seen that an increase in oil prices will increase the number of vessels handled by Emam Khomeini port; however, at the same time the tonnage of goods loaded and discharged in this port significantly decreases. This means that vessels calling at this port despite the larger number have lower deadweight tonnage. Since vessels with lower DWT are generally used in regional trade, it can be concluded that rising of oil prices in the short term will strengthen the seaborne trade of this port at the regional level. It can also be concluded that the imported goods at the time of rising oil prices are mainly industrial and expensive cargoes that have less volume than bulk commodities. Only an increase in China's GDP will increase the port throughput of Emam Khomeini port marginally, and the increase in the GDP of Korea and Germany reduces the throughput of the port in the short term.

\section{Bushehr Port}

Similar to the results for Emam Khomeini's port model, rising oil prices will increase the number of vessels handled by Bushehr port, but at the same time it reduces the tonnage of goods loaded and discharged in this port. Moreover, in this case it can be concluded that vessels calling at this port have a lower DWT; thus, seaborne trade of this port increases at the regional level. In addition, it can be determined that imported goods at the time of rising oil prices are mainly industrial and expensive cargoes. Initial shock to Germany's GDP increases the throughput of this port insignificantly in the first and second periods. The impact of China's and South Korea's GDP growth on the throughput of the Bushehr port is almost the same. In the short run, an increase in the GDPs of China and South Korea will increase the number of vessels handled by this port and slightly reduce the tonnage of goods loaded and discharged in this port. The results are shown in Figure 6. 


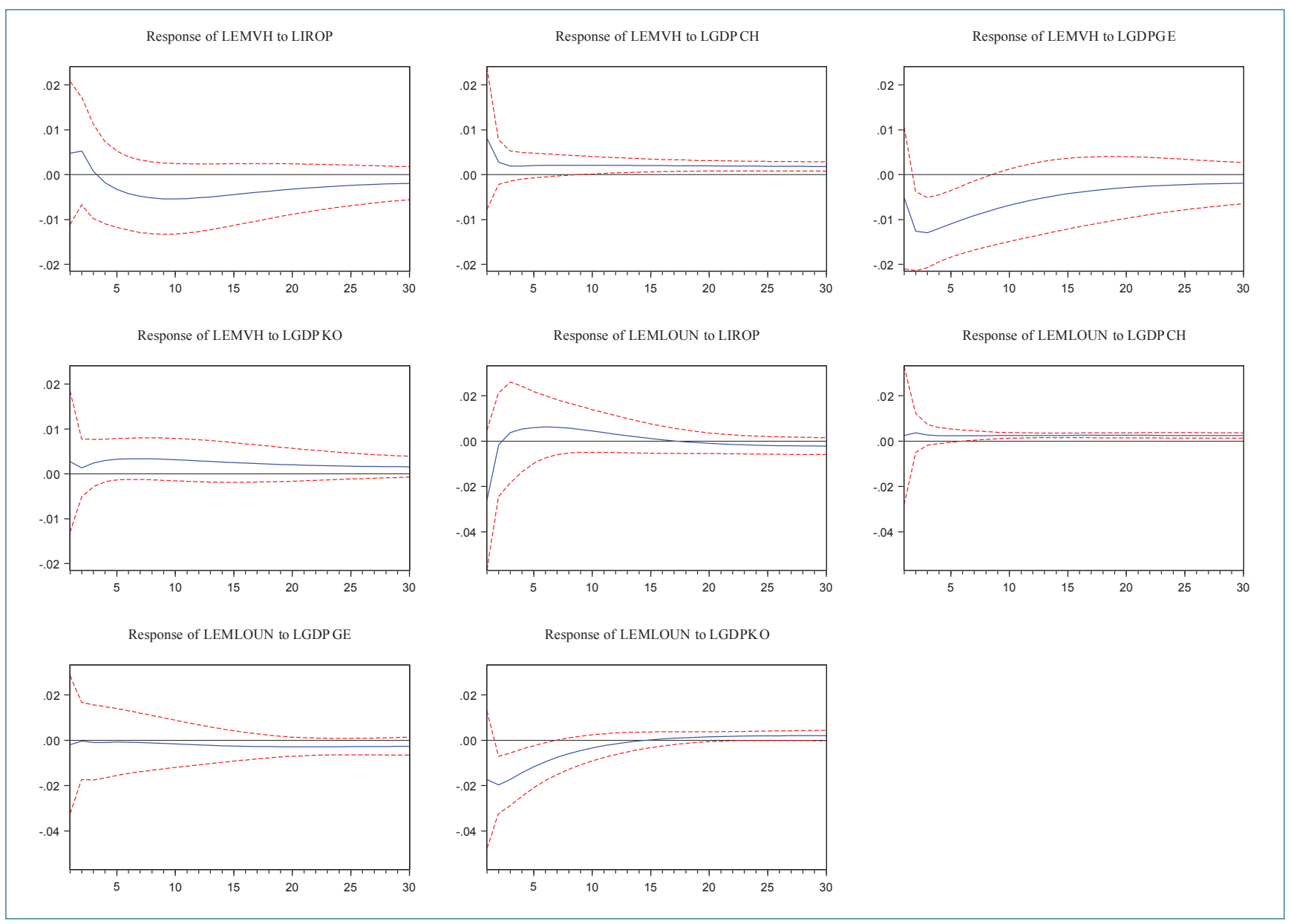

Figure 5.

IRFs for Emam Khomeyni port VAR model.

\subsection{Forecast Error Variance Decomposition}

Forecast Error Variance Decomposition is a method for evaluating a VAR model's dynamics. This method examines the variations of dependent variables due to the shocks applied to a variable against the shocks applied to other variables. In this study, shocks applied to oil price variable transfer to other variables. Forecast Error Variance Decomposition specifies how much the effect of shocks is due to various factors. Furthermore, forecast error variance decomposition enables us to determine which variable is stronger in explaining the variability in the dependent variables over time. It also indicates how much of the future uncertainty of a time series is due to future shocks in other time series in the VAR system. The following subsections explain Forecast Error Variance Decomposition for each VAR model.

\section{Shahid Rajaei Port}

As shown in Table 5, the share of oil price fluctuations in explaining variations in the number of vessels handled by this port is low, which increases in the early periods, but decreases in the long run. The share of oil price volatility in explaining the variations in the tonnage of goods loaded and unloaded in Shahid Rajaei port is low in the early periods, but then after several periods, it increases significantly. In explaining the variations in Shahid Rajaei port throughput, fluctuations in Germany's GDP have a stronger short- and long-run role compared to fluctuations in China's and South Korea's GDPs. The share of Germany's GDP in explaining changes in the tonnage of goods loaded and discharged in this port is remarkable in the long run. Since Germany has always been the largest trade partner of Iran among the industrialized economies, it can be concluded that this port is affected by technology and investment spillovers, which in the long run contribute to the country's economic development and will increase the throughput of this port. 


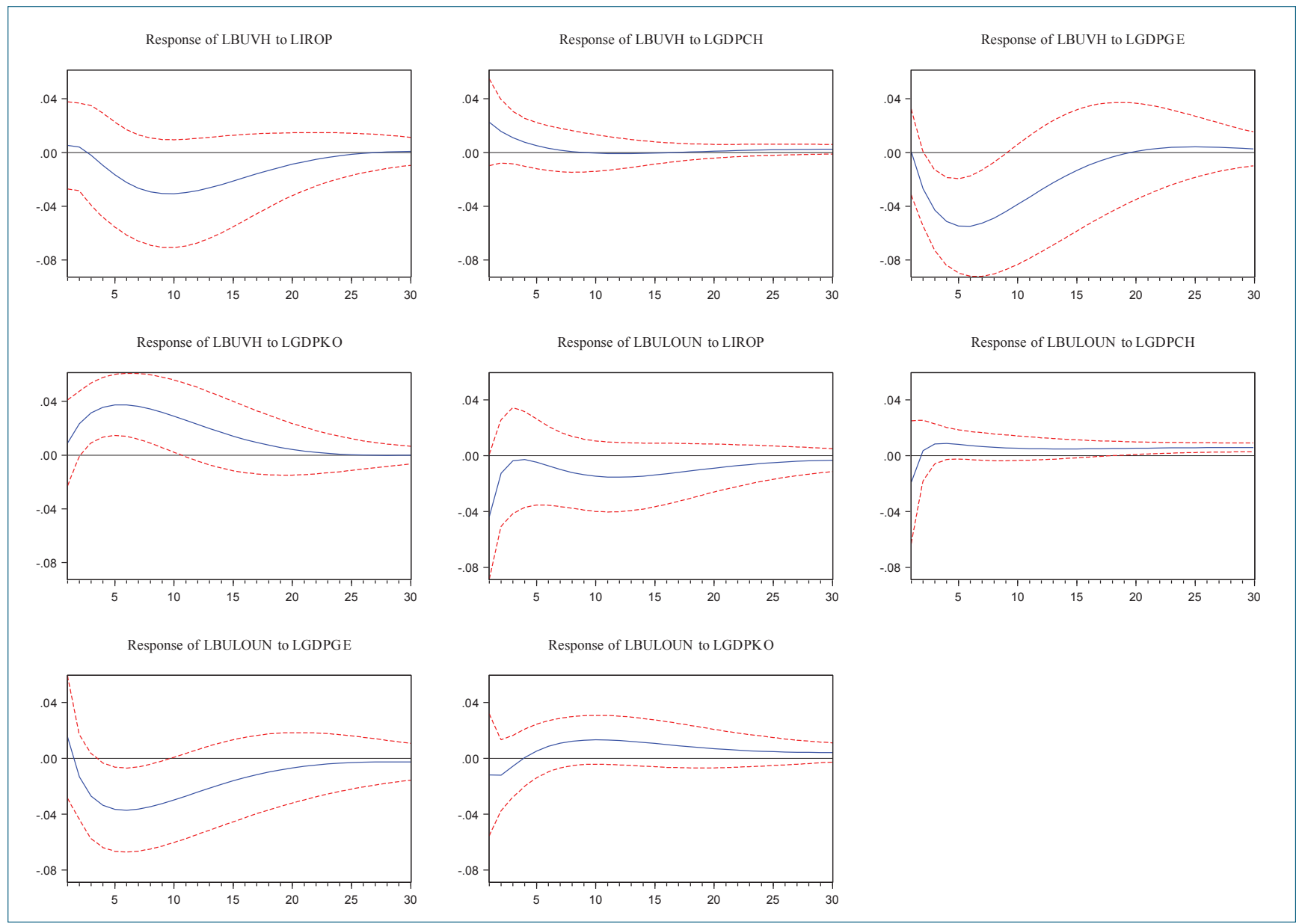

Figure 6.

IRFs for Bushehr port VAR model.

Table 5.

Variance Decomposition of LRAVH and LRALOUN.

\begin{tabular}{|c|c|c|c|c|c|c|}
\hline Quarter & LIROP & LGDPCH & LGDPGE & LGDPKO & LRAVH & LRALOUN \\
\hline \multicolumn{7}{|c|}{ Variance Decomposition of LRAVH: } \\
\hline 1 & 1.45 & 0.93 & 4.95 & 1.16 & 91.48 & 0.00 \\
\hline 4 & 5.37 & 1.24 & 13.41 & 0.93 & 77.13 & 1.89 \\
\hline 8 & 6.50 & 1.27 & 25.56 & 1.05 & 63.45 & 2.14 \\
\hline 12 & 6.07 & 1.25 & 31.93 & 1.57 & 56.91 & 2.24 \\
\hline \multicolumn{7}{|c|}{ Variance Decomposition of LRALOUN: } \\
\hline 1 & 2.19 & 3.51 & 0.12 & 0.001 & 7.33 & 86.82 \\
\hline 4 & 18.90 & 2.99 & 12.12 & 0.03 & 5.53 & 60.40 \\
\hline 8 & 18.68 & 2.62 & 29.98 & 0.65 & 4.25 & 43.79 \\
\hline 12 & 16.08 & 2.47 & 38.76 & 1.79 & 3.67 & 37.21 \\
\hline
\end{tabular}


Table 6.

Variance Decomposition of LEMVH and LEMLOUN.

\begin{tabular}{|c|c|c|c|c|c|c|}
\hline Quarter & LIROP & LGDPCH & LGDPGE & LGDPKO & LEMVH & LEMLOUN \\
\hline \multicolumn{7}{|c|}{ Variance Decomposition of LEMVH: } \\
\hline 1 & 0.48 & 1.39 & 0.57 & 0.15 & 97.39 & 0.00 \\
\hline 4 & 0.99 & 1.47 & 9.05 & 0.43 & 83.83 & 4.20 \\
\hline 8 & 2.22 & 1.62 & 14.48 & 1.13 & 76.64 & 3.88 \\
\hline 12 & 3.88 & 1.80 & 16.41 & 1.66 & 72.46 & 3.76 \\
\hline \multicolumn{7}{|c|}{ Variance Decomposition of LEMLOUN: } \\
\hline 1 & 3.78 & 0.03 & 0.021 & 1.68 & 30.38 & 64.07 \\
\hline 4 & 3.69 & 0.16 & 0.029 & 6.10 & 30.69 & 59.31 \\
\hline 8 & 4.32 & 0.27 & 0.04 & 7.53 & 29.94 & 58.87 \\
\hline 12 & 4.63 & 0.39 & 0.10 & 7.67 & 29.72 & 57.46 \\
\hline
\end{tabular}

Table 7.

Variance Decomposition of LBUVH and LBULOUN.

\begin{tabular}{|c|c|c|c|c|c|c|}
\hline Quarter & LIROP & LGDPCH & LGDPGE & LGDPKO & LBUVH & LBULOUN \\
\hline \multicolumn{7}{|c|}{ Variance Decomposition of LBUVH: } \\
\hline 1 & 0.14 & 2.59 & 0.00 & 0.42 & 96.83 & 0.00 \\
\hline 4 & 0.35 & 2.32 & 12.99 & 7.19 & 76.83 & 0.29 \\
\hline 8 & 4.16 & 1.63 & 27.54 & 13.75 & 52.57 & 0.32 \\
\hline 12 & 8.30 & 1.33 & 29.73 & 15.38 & 44.96 & .026 \\
\hline \multicolumn{7}{|c|}{ Variance Decomposition of LBULOUN: } \\
\hline 1 & 5.02 & 0.95 & 0.61 & 0.37 & 13.66 & 79.38 \\
\hline 4 & 4.21 & 1.05 & 4.59 & 0.64 & 21.29 & 68.18 \\
\hline 8 & 4.29 & 1.28 & 13.45 & 1.23 & 19.35 & 60.38 \\
\hline 12 & 5.35 & 1.35 & 17.63 & 2.24 & 18.15 & 55.24 \\
\hline
\end{tabular}

\section{Emam Khomeini Port}

Table 6 shows the results of Forecast Error Variance Decomposition for the VAR model of Emam Khomeini port. Although the share of oil price fluctuations in explaining changes in the throughput of Emam Khomeini port increases over time, it is much lower in comparison with Shahid Rajaei port. The share of Germany's GDP in the explanation of changes in the number of vessels handled by the port increases dramatically, but this share is very low and below 1 per cent in explaining the variations in the tonnage of goods loaded and discharged in this port. Besides, the share of China's and South Korea's GDPs, although rising are not significant. Indeed, most of the fluctuations of Emam Khomeini port throughput are explained by their own past shocks. The reason is that raw materials and agricultural commodities, which are the primary requirements of the country, account for the highest share of the goods loaded and discharged in this port, while the share of industrial goods and containers is much lower. Therefore, regardless of the changes in oil prices and the increase or decrease in oil revenues, raw materials and agricultural commodities have always been imported to the extent required in all circumstances. 


\section{Bushehr Port}

Similar to the port of Emam Khomeini, the share of oil price fluctuations in the explanation of changes in the throughput of Bushehr port increases over time; however, in the long run this increase is much lower compared to Shahid Rajaei port. In the long run, the share of South Korea's GDP in explaining the fluctuations of the number of vessels handled by Bushehr port increases rapidly, but this share is modest in explaining the variations of the tonnage of goods loaded and discharged in this port and does not change considerably over time. Like Shahid Rajaei port, the share of fluctuations in Germany's GDP in explaining the changes in the throughput of Bushehr port is low in the early periods, but increases considerably in the long run. Consequently, Bushehr port benefits from the technology and investment spillovers over time. The share of China's GDP is marginal in both the short and long run, and does not change significantly over time. The results are shown in Table 7.

\section{CONCLUSIONS AND POLICY DISCUSSION}

In the present research, an attempt was made to estimate the effects of oil price shocks on port throughput in the three major ports in Iran, i.e. Shahid Rajaei, Emam Khomeini, and Bushehr, through economic fluctuations of the three major trading partners. The number of vessels handled by each port and the tonnage of goods loaded and discharged in each port were chosen as indicators of port throughput. Besides, the seasonal average of Iran's heavy crude oil price was selected as the indicator of oil price shocks, and GDP in constant prices of 2010 was chosen as the indicator of economic fluctuations of Iran's major trading partners. The sample of trading partners consists of three countries: China, South Korea, and Germany. The data used in this study was quarterly, covering the period from 1999 Q2 to 2018 Q1. We applied the vector autoregressive (VAR) approach using Cholesky decomposition.

Analysis of the Impulse Response functions for each VAR model shows that in the short run and with increasing oil revenues, seaborne trade will be further directed towards Shahid Rajaei Port as the largest commercial port in Iran. Rising oil revenues in the short term will change the combination of goods loaded and discharged in the ports of Emam Khomeini and Bushehr. Furthermore, the results of forecast error variance decomposition tables show that in the long run the share of oil price fluctuations in explaining the variations of Shahid Rajaei port throughput is higher than the other two ports. In addition, these tables show that fluctuations in Emam Khomeini port throughput are also explained by changes in the past values of the dependent variables. Besides, the results of forecast error variance decomposition indicated that the share of China's and
South Korea's GDP fluctuations in explaining the changes in the throughput of Iran ports in the short and long term are low and do not change considerably over time. However, the share of Germany's GDP fluctuations in explaining the variations in the port throughput of Shahid Rajaei and Bushehr ports are low in the short run, but in the long run will increase dramatically. Indeed, the results of the research prove the fact that by increasing GDP the macroeconomic system tends to be more open. On the other hand, increasing oil revenues results in GDP growth. There is a close relationship between GDP, containerized cargo trade, and open macroeconomic systems. Consequently, increases in oil revenues cause an increase in the volume of industrial and containerized seaborne cargo trade. Actually, economic growth deceleration causes a decline in merchandise trade, increased trade policy uncertainty, and the negative impact of low-price commodities trade on export earnings. According to the results of the models, the policy suggestions include:

- Permanent monitoring of fluctuations in oil prices and prospects in this market.

- Ports specialization is one of the prerequisites for the attainment of the fourth generation of ports. Considering the need of the country to attain the fourth generation of ports, the specialization of Shahid Rajaei and Bushehr ports in handling industrial commodities and containers, and the specialization of Emam Khomeini port in handling bulk commodities as well as raw materials are proposed in order to increase the throughput of these ports.

- Increasing the seaborne trade volume with industrial economies.

\section{APPENDIX A. LAG LENGTH SELECTION}

The optimal lag length for each VAR model is determined based on the Schwarz information criterion (SC) and HannanQuinn information criterion (HQ). The results are reported in Tables A.1 to A.3.

Table A.1

Optimal lag length for VAR model of Shahid Rajaei Port.

\begin{tabular}{lll} 
Lag & SC & HQ \\
\hline 0 & -13.28907 & $-24.88955^{*}$ \\
\hline 1 & -23.86283 & -22.40962 \\
\hline 2 & -21.12502 & -13.52347 \\
\hline 3 & $-25.82712^{*}$ & -25.50358 \\
\hline 4 & -24.75356 & -24.17214 \\
\hline
\end{tabular}


Table A.2

Optimal lag length for VAR model of Emam Khomeyni Port.

\begin{tabular}{lll} 
lag & SC & HQ \\
\hline 0 & -13.88260 & $-24.48683^{*}$ \\
\hline 1 & -23.60555 & -22.33395 \\
\hline 2 & -21.04975 & -14.11699 \\
\hline 3 & $-25.42440^{*}$ & -25.24630 \\
\hline 4 & -24.67788 & -24.09686 \\
\hline
\end{tabular}

\section{Table A.3}

Optimal lag length for VAR model of Bushehr Port

\begin{tabular}{lll} 
lag & SC & HQ \\
\hline 0 & -10.90809 & $-22.21277^{*}$ \\
\hline 1 & -21.48239 & -19.87927 \\
\hline 2 & -18.64248 & -11.14248 \\
\hline 3 & $-23.15035^{*}$ & -23.12315 \\
\hline 4 & -22.22320 & -21.68959 \\
\hline
\end{tabular}

\section{REFERENCES}

Basher, S.A., Haug, A.A. \& Sadorsky, P., 2016. The impact of oil shocks on exchange rates: A Markov-switching approach. Energy Economics, 54, pp.11-23. Available at: https://dx.doi.org/10.1016/j.eneco.2015.12.004

Chen, H. et al., 2016. Oil price shocks and U.S. dollar exchange rates. Energy, 112, pp.1036-1048. Available at: https://dx.doi.org/10.1016/j.energy.2016.07.012.

Dauvin, M., 2014. Energy prices and the real exchange rate of commodity-exporting countries. International Economics, 137, pp.52-72. Available at: https://dx.doi.org/10.1016/j.inteco.2013.11.001.

Dickey, D.A. \& Fuller, W.A., 1979. Distribution of the Estimators for Autoregressive Time Series with a Unit Root. Journal of the American Statistical Association, 74(366a), pp.427-431. Available at: https://dx.doi.org/10.1080/01621459.1979.10482531

Economou, A. \& Agnolucci, P., 2016. Oil Price Shocks: A Measure of the Exogenous and Endogenous Supply Shocks of Crude Oil. SPE Annual Technical Conference and Exhibition. Available at:

https://dx.doi.org/10.2118/181542-ms.

Farzanegan, M.R. \& Markwardt, G., 2009. The effects of oil price shocks on the Iranian economy. Energy Economics, 31(1), pp.134-151. Available at: https://dx.doi.org/10.1016/j.eneco.2008.09.003.

Granger, C.W.J. \& Newbold, P., 1974. Spurious regressions in econometrics. Journal of Econometrics, 2(2), pp.111-120. Available at:

https://dx.doi.org/10.1016/0304-4076(74)90034-7.
Iran's Port and Maritime Organization, 2018. Available at: https://amar.pmo.ir/ default.aspx, accessed on: November 22nd 2018.

Iran's Port and Maritime Organization, 2018. System operations statistics.

Johansen, S., 1991. Estimation and Hypothesis Testing of Cointegration Vectors in Gaussian Vector Autoregressive Models. Econometrica, 59(6), pp.1551-1580. Available at:

https://dx.doi.org/10.2307/2938278

Johansen, S., 1995. Likelihood-Based Inference in Cointegrated Vector Autoregressive Models. Available at:

https://dx.doi.org/10.1093/0198774508.001.0001.

Kim, C.B., 2016. Impact of Exchange Rate Movements, Global Economic Activity, and the BDI Volatility on Loaded Port Cargo Throughput in South Korea. The Asian Journal of Shipping and Logistics, 32(4), pp.243-248. Available at: https://dx.doi.org/10.1016/j.ajsl.2016.12.008.

Korhonen, I. \& Ledyaeva, S., 2010. Trade linkages and macroeconomic effects of the price of oil. Energy Economics, 32(4), pp.848-856. Available at: https://dx.doi.org/10.1016/j.eneco.2009.11.005.

Le, T.-H. \& Chang, Y., 2013. Oil price shocks and trade imbalances. Energy Economics, 36, pp.78-96. Available at:

https://dx.doi.org/10.1016/j.eneco.2012.12.002

Mehdi-Zadeh, C., 2018. Iranian Economy Post-JCPOA and its Ambitions. Global Policy, 9(1), pp.153-155. Available at: https://dx.doi.org/10.1111/1758-5899.12535.

OPEC, 2005. Annual Report 2004.

OPEC, 2018. Annual Statistical Bulletin. Available at: https://asb.opec.org/index. php/data-download, accessed on: November 15th 2018

Phillips, P.C.B. \& Perron, P., 1988. Testing for a Unit Root in Time Series Regression. Biometrika, 75(2), p.335. Available at: https://dx.doi.org/10.2307/2336182.

Raheem, I.D., 2017. Asymmetry and break effects of oil price -macroeconomic fundamentals dynamics: The trade effect channel. The Journal of Economic Asymmetries, 16, pp.12-25. Available at: https://dx.doi.org/10.1016/j.jeca.2017.04.002

Sims, C.A., 1980. Macroeconomics and Reality. Econometrica, 48(1), p.1. Available at: https://dx.doi.org/10.2307/1912017.

Taghizadeh Hesary, F., Yoshino, N., Abdoli, G., \& Farzinvash, A., 2013. An estimation of the impact of oil shocks on crude oil exporting economies and their trade partners. Frontiers of Economics in China, 8(4), pp.571-591, available at: https://doi.org/10.3868/s060-002-013-0029-3

United Nations Conference on Trade and Development, 2017. Handbook of Statistics 2017, Maritime Transport, pp.71.

United States Department of Transportation, Bureau of Transportation, 2017 Available at: https://www.bts.gov/archive/publications/port_performance_freight_ statistics annual report/2016/ch3/, accessed on: May 20th 2017.

Volkov, N.I. \& Yuhn, K., 2016. Oil price shocks and exchange rate movements. Global Finance Journal, 31, pp.18-30. Available at: http://dx.doi.org/10.1016/j.gff.2016.11.001. 